\title{
EKSTRAKSI DAN STRIPPING TORIUM DARI RAFINAT HASIL EKSTRAKSI URANIUM MONASIT BANGKA
}

\author{
Rida Ferliana ${ }^{1}$, Bangun Wasito ${ }^{1}$, Riesna Prassanti ${ }^{2}$ \\ 1) Teknokimia Nuklir STTN-BATAN, J1. Babarsari, Kotak Pos 6101 YKBB Yogyakarta \\ 55281 \\ 2) PTBGN-BATAN, Jl. Lebak Bulus Raya No.9. Ps. Jumat, Jakarta 12440
}

\begin{abstract}
ABSTRAK
EKSTRAKSI DAN STRIPPING TORIUM DARI RAFINAT HASIL EKSTRAKSI URANIUM MONASIT BANGKA. Pusat Teknologi Bahan Galian Nuklir-Badan Tenaga Nuklir Nasional (PTBGN-BATAN) yang bekerja sama dengan PT Timah mengimplementasikan penelitian pengolahan monasit menjadi logam tanah jarang ke dalam skala pilot plant $50 \mathrm{~kg} / \mathrm{hari}$. Kegiatan tersebut menghasilkan limbah berupa unsur radioaktif, seperti uranium dan torium. Torium merupakan alternatif pengganti bahan bakar uranium. Agar dapat dijadikan bahan bakar nuklir, torium perlu dipisahkan terlebih dahulu. Salah satu metode pemisahan adalah ekstraksi-stripping. Ekstraksi-stripping torium dilakukan dengan menggunakan rafinat hasil ekstraksi uranium pada limbah pengolahan monasit. Solvent yang digunakan dalam ekstraksi adalah TBP dan dalam stripping adalah $\mathrm{HNO}_{3}$ encer. Berdasarkan penelitian diperoleh bahwa semakin tinggi keasaman umpan, maka recovery dan koefisien distribusi torium semakin meningkat; serta semakin tinggi konsentrasi $\mathrm{HNO}_{3}$, maka recovery semakin menurun dan koefisien distribusi torium semakin meningkat. Ekstraksi selama 15 menit, $\mathrm{pH}$ umpan 0,09 , TBP/kerosen 50/50, dan perbandingan $\mathrm{A} / \mathrm{O}=1 / 1$ memberikan koefisien distribusi sebesar 13,80 dengan recovery ekstraksi sebesar 93\%. Stripping selama 15 menit, konsentrasi $\mathrm{HNO}_{3} 0,1 \mathrm{~N}$, dan perbandingan $\mathrm{A} / \mathrm{O}=1 / 1$ memberikan koefisien distribusi 1,57 dengan recovery sebesar $38,92 \%$. Jika recovery torium ingin ditingkatkan menjadi 95\%, maka dibutuhkan 2 stage ekstraksi pada perbandingan $\mathrm{A} / \mathrm{O}$ $=1 / 1,8$ stage stripping pada perbandingan $\mathrm{A} / \mathrm{O}=2 / 1$, dan 5 stage stripping pada perbandingan $\mathrm{A} / \mathrm{O}=3 / 1$.
\end{abstract}

Kata kunci: monasit, ekstraksi, stripping, torium, uranium, logam tanah jarang, koefisien distribusi, stage

\begin{abstract}
THORIUM EXTRACTION AND STRIPPING FROM URANIUM EXTRACTION RAFFINATE OF BANGKA MONAZITE. Centre for Nuclear Mineral Geology-National Nuclear Energy Agency in cooperation with PT Timah (TINS) has conducted a project of turning monazite into rare earth elements pilot plant of $50 \mathrm{~kg} /$ day. This project would produce radioactive wastes such as uranium and thorium. Thorium is an alternative fuel source to uranium. In order to be able to be used as nuclear fuel, the impurities must be separated from the thorium. One of the separation methods is extraction-stripping. Extraction and stripping of thorium was made by using raffinate of uranium extraction of rare earth elements wastes. Solvent used in extraction is $T B P$ and in stripping is diluted acid. This research showed that the higher the acidity of feed, the more possibility of recovery and distribution coefficients of thorium will increase in the extraction; and the higher the concentration of $\mathrm{HNO}_{3}$, the more possibility of recovery will decrease and distribution coefficients of thorium in the stripping will increase. Extraction in 15 minutes, with feed $p H$ 0,09, TBP/kerosene 50/50, and $A / O=1 / 1$ resulted in a distribution coefficient of 13,8 with the recovery of thorium to be 93,24\%. Stripping in 15 minutes, with $\mathrm{HNO}_{3} \mathrm{O}, 1 \mathrm{~N}$, and $\mathrm{A} / \mathrm{O}=1 / 1$ resulted in a distribution coefficient of 1,57 with the recovery of thorium to be $38,92 \%$. To increase recovery of thorium up to $95 \%$, it would need two stages of extraction of $A / O=1 / 1,8$ stages of stripping of $A / O=2 / 1$, and 5 stages of stripping of $A / O=3 / 1$.
\end{abstract}

Keywords: monazite, extraction, stripping, thorium, uranium, rare earth element, distribution coefficient, stage 


\section{PENDAHULUAN}

Monasit merupakan senyawa fosfat logam tanah jarang yang mengandung oksida logam tanah jarang, uranium, dan torium. Monasit Bangka merupakan hasil samping pencucian bijih timah oleh PT Timah. Monasit tersebut mengandung unsur-unsur logam tanah jarang sebesar $50,97 \%$, uranium $0,298 \%$, torium $4,147 \%$, dan fosfat $23,712 \%$ [1]. Logam tanah jarang dapat digunakan pada energi nuklir, kimia, katalisator, elektronik, dan optik. Uranium dan torium digunakan sebagai bahan bakar nuklir, sedangkan fosfat digunakan dalam industri pupuk.

PTBGN-BATAN bekerja sama dengan PT Timah melakukan penelitian pengolahan monasit secara basa, dengan tahapan: preparasi monasit, dekomposisi, pelarutan parsial, pengendapan $\mathrm{U}$ dan Th, serta pengendapan $\quad \mathrm{RE}(\mathrm{OH})_{3} \quad$ seperti yang ditunjukkan pada Gambar 1. Berdasarkan hasil analisis di Laboratorium Chemex Canada, diperoleh $\mathrm{RE}_{2} \mathrm{O}_{3}>55,23 \%, \mathrm{U}<2$ ppm, dan Th 16 ppm, sedangkan hasil analisis di laboratorium Alfred H.K., London diperoleh $\mathrm{RE}_{2} \mathrm{O}_{3} 76,12 \%$, dengan $\mathrm{U}$ dan $\mathrm{Th}<$ $50 \mathrm{ppm}$ [2].

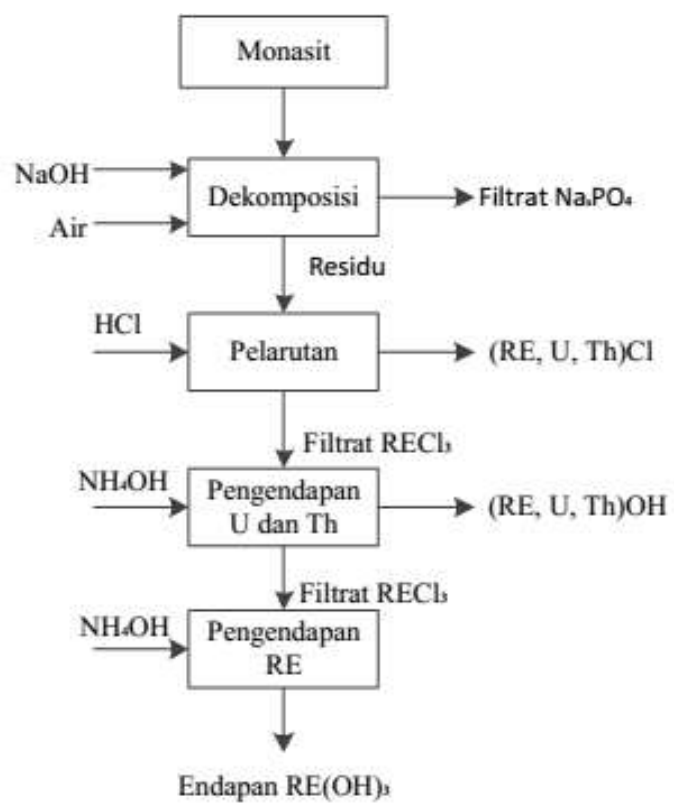

Gambar 1. Pengolahan Monasit Secara Basa oleh PTBGN-BATAN [3]

Penelitian tersebut diimplementasikan dalam pilot plant $50 \mathrm{~kg} / \mathrm{hari}$ sehingga hasil samping yang berupa uranium dan torium perlu dipikirkan. Meskipun paparan yang diterima masyarakat sangat rendah, pencemaran uranium dan torium sangat tidak diharapkan. Uranium-238 dan torium-232 merupakan penghasil radiasi alfa sehingga dapat menimbulkan bahaya internal yang sangat tinggi. Dengan mengambil atau mengolahnya, uranium dan torium dapat menjadi bahan bakar nuklir.

Agar dapat dijadikan bahan bakar nuklir, torium harus memiliki kemurnian tinggi, yakni lebih dari $87,42 \%$ [4]. Penelitian Trinopiawan dkk. mengenai pemisahan uranium dari torium dengan ekstraksi menggunakan alamin memberikan recovery uranium $100 \%$, torium $32,44 \%$, logam tanah jarang 2,24\%, dan fosfat tidak terdeteksi [5]. Berdasarkan hasil tersebut, uranium sudah mampu diambil, namun torium dan logam tanah jarang dalam rafinat masih sangat tinggi. Logam tanah jarang seperti gadolinium, samarium, dan disprosium merupakan penyerap neutron yang sebaik elemen boron dan kadmium [6] sehingga torium harus dipisahkan dari logam tanah jarang.

Dalam penelitian ini akan dilakukan pemisahan torium dari rafinat hasil ekstraksi uranium dengan metode ekstraksi-stripping. Penelitian mengenai pemurnian torium menggunakan TBP sudah pernah dilakukan, namun umpan yang digunakan berbeda serta ada beberapa kondisi yang perlu dicari. Pada penelitian ini akan ditentukan pengaruh $\mathrm{pH}$ umpan dalam ekstraksi torium. $\mathrm{pH}$ umpan yang diperoleh kemudian dapat dijadikan pengontrol dalam pelarutan umpan. Setelah proses ekstraksi, dilakukan pengembalian fase organik ke dalam fase aqueous melalui proses stripping. Data mengenai koefisien distribusi stripping belum ditemukan sehingga perlu ditentukan besarnya koefisien distribusi pada setiap variasi konsentrasi stripper.

Penelitian ini difokuskan untuk mencari jumlah stage yang dibutuhkan untuk perancangan. Koefisien distribusi ekstraksi dan data-data yang sudah ada dapat dijadikan sebagai acuan penelitian.

\section{TEORI}

\section{Ekstraksi Torium Menggunakan TBP}

Ekstraksi merupakan proses pemisahan satu atau lebih zat terlarut dari larutannya dengan menggunakan pelarut lain. Solvent yang sering digunakan dalam pemurnian torium adalah TBP, yaitu senyawa organofosfat yang bersifat netral yang mempunyai rumus struktur 
molekul seperti pada Gambar 2. Atom oksigen pada gugus $\mathrm{P}=\mathrm{O}$ merupakan basa lewis dan bertindak sebagai atom donor yang dapat memberikan pasangan elektron bebas pada orbital kosong torium, uranium, dan LTJ [9].

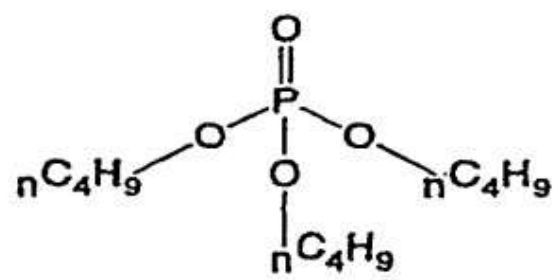

Gambar 2. Struktur Tri-butil-fosfat

\section{Stripping Torium}

Ekstraksi uranium menggunakan TBP lebih kuat dibandingkan pada torium dan logam tanah jarang. Langkah penting dalam pemisahan uranium dan torium adalah stripping. Pada proses stripping, torium dapat diambil dari ekstraksi TBP dengan menggunakan asam encer, sedangkan uranium dapat diambil dengan menggunakan air demineralisasi [6].

\section{Koefisien Distribusi}

Dalam ekstraksi maupun stripping, ketika larutan aqueous dikontakkan dengan solvent yang tidak saling melarutkan, komponen yang diekstrak akan ditemukan terdistribusi di antara dua fase, yaitu fase organik dan fase aqueous. Distribusi ini dapat dinyatakan dengan koefisien distribusi. Salah satu faktor penting dalam pemisahan ekstraksi-stripping adalah koefisien distribusi, yang dinyatakan dalam Persamaan (1).

$$
K d=\frac{[\text { unsur }]_{\text {organik }}}{[\text { unsur }]_{\text {aqueous }}}
$$

Nilai koefisien distribusi pada ekstraksi diharapkan tinggi, sedangkan nilai koefisien distribusi pada stripping diharapkan rendah [7].

\section{Ekstraksi Multistage dengan Aliran Berlawanan Arah (Counter Current)}

Prinsip ekstraksi multistage counter current adalah mengontakkan umpan "baru" dengan solvent yang telah mengandung banyak solute. Solute tersebut merupakan ekstrak yang diperoleh sebagai hasil kontak pada stage berikutnya. Kemudian, umpan dengan solute yang telah menipis dikontakkan dengan pelarut pada tahap berikutnya, seperti pada Gambar 3.

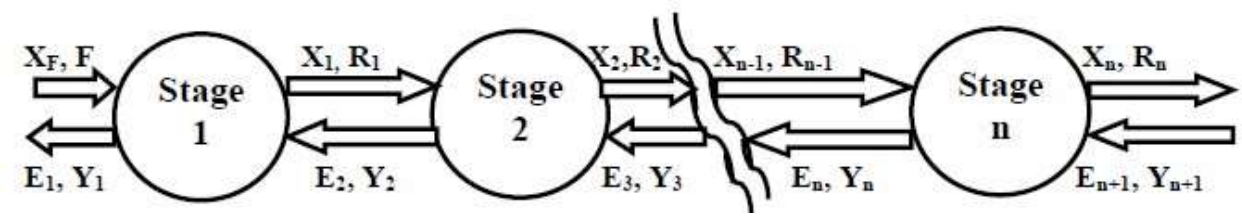

Gambar 3. Ekstraksi Multistage Berlawanan Arah [7]

Jumlah stage yang dibutuhkan dapat ditentukan dengan cara berikut.

\section{a. Metode Grafik McCabe-Thiele}

Persamaan garis operasi dapat ditentukan dengan membuat neraca massa berdasarkan Gambar 3.

Neraca massa pada setiap stage dinyatakan dengan Persamaan (2).

$$
\mathrm{FX}_{\mathrm{F}}+\mathrm{SY}_{\mathrm{n}+1}=\mathrm{RX}_{\mathrm{n}}+\mathrm{EY}_{1}
$$

Karena solvent dan larutan umpan tidak saling melarutkan maka $\mathrm{F}=\mathrm{R}$ dan $\mathrm{S}=\mathrm{E}$ sehingga Persamaan (2) dapat diubah menjadi:

$$
\mathrm{FX}_{\mathrm{F}}+\mathrm{SY}_{\mathrm{n}+1}=\mathrm{FX}_{\mathrm{n}}+\mathrm{SY}_{1}
$$

$$
Y_{n+1}=\frac{F}{S}\left(X_{n}-X_{F}\right)+Y_{1}
$$

$\mathrm{X}_{\mathrm{n}}$ adalah fraksi massa solute dalam rafinat yang meninggalkan proses; $\mathrm{X}_{\mathrm{F}}$ adalah fraksi massa solute dalam umpan yang masuk ke proses; $\mathrm{F}$ adalah kecepatan aliran massa umpan, $S$ adalah kecepatan aliran massa solvent, dan $\mathrm{Y}_{\mathrm{n}+1}=\mathrm{Y}_{\mathrm{s}}$ adalah fraksi massa solute dalam ekstraktan yang masuk ke proses.

Metode McCabe-Thiele juga dapat diterapkan berdasarkan konsentrasi solute di dalam ekstrak dan rafinat. Definisi laju alir, konsentrasi, dan jumlah stage ditunjukkan pada Gambar 4 dengan mengasumsikan bahwa kesetimbangan dicapai antara fase aqueous dan fase organik yang meninggalkan masingmasing stage. 


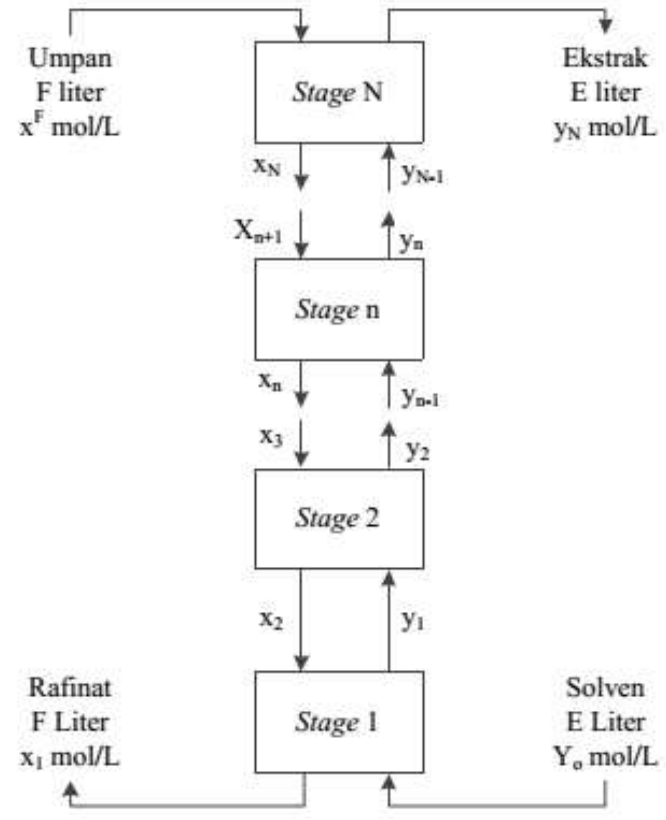

Gambar 4. Definisi Laju Alir Volume,

Konsentrasi, dan Jumlah Stage pada Ekstraksi Bertingkat [7]
Konsentrasi dalam organik dan aqueous dinyatakan dengan persamaan berikut.

$\mathrm{Y}_{\mathrm{n}}=\mathrm{D}_{\mathrm{n}} \mathrm{X}_{\mathrm{n}}$

D merupakan koefisien distribusi pada stage ke-n.

Neraca massa sesuai dengan Gambar 4 dinyatakan dengan persamaan berikut.

$E_{y_{n}}+F_{x_{n}}=E_{y_{n-1}}+F_{x_{1}}$

$y_{n-1}-y_{0}=\frac{F}{E}\left(x_{n}-x_{1}\right)$

Neraca massa dapat ditampilkan menggunakan garis operasi yang melewati titik $\left(\mathrm{x}_{1}, \mathrm{y}_{0}\right)$ dan memiliki slope $\mathrm{F} / \mathrm{E}$. Persamaan (5) dapat ditampilkan dengan menarik garis kesetimbangan. Contoh garis kesetimbangan dan garis operasi berdasarkan konsentrasi dapat dilihat pada Gambar 5.

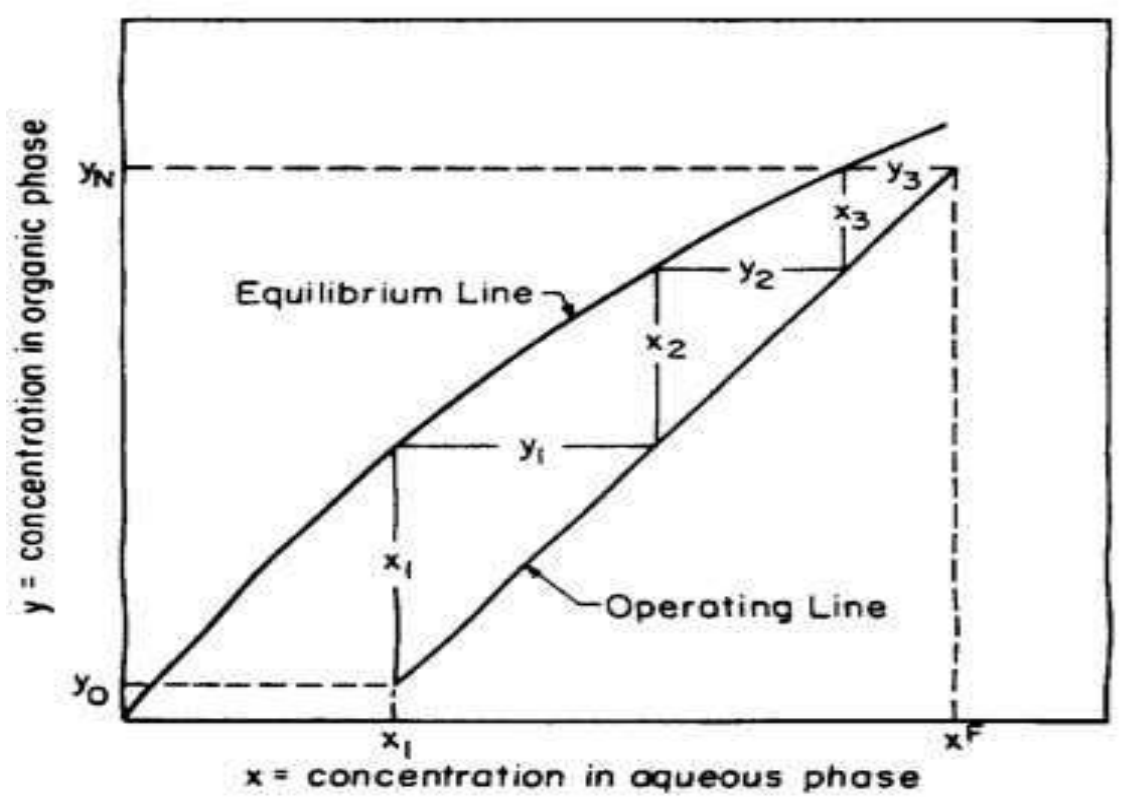

Gambar 5. Kurva Kesetimbangan dalam Penentuan Jumlah Stage Berdasarkan Konsentrasi [7]

\section{b. Metode Shortcut}

Ketika garis kesetimbangan lurus, intersep nol, dan garis operasi lurus, jumlah stage dapat dihitung dengan persamaan Kremser pada Persamaan (8) dan (9).[8]

$$
N=\frac{\ln \left[\left(\frac{X_{F}-Y_{S} / m}{X_{r}-Y_{S} / m}\right)\left(1-\frac{1}{\varepsilon}\right)+\frac{1}{\varepsilon}\right]}{\ln \varepsilon}
$$

Jika $\varepsilon=1$,
$N=\frac{X_{F}-Y_{S} / m}{X_{r}-Y_{S} / m}-1$

dengan $\varepsilon=\frac{m}{F / S}=$ faktor ekstraksi

\section{METODOLOGI}

\section{Bahan}

Larutan (U, Th, RE) $\mathrm{SO}_{4}$ sebagai umpan ekstraksi uranium dibuat dari residu pelarutan 
parsial pada pengolahan monasit menjadi logam tanah jarang, ekstraktan uranium yaitu larutan TOA/kerosen/isodekanol, ekstraktan torium yaitu larutan TBP/kerosen, larutan stripper yaitu $\mathrm{HNO}_{3}$ encer, $\mathrm{NH}_{4} \mathrm{OH}$ sebagai reagen pengendap rafinat ekstraksi uranium, $\mathrm{HNO}_{3}$ sebagai pelarut umpan ekstraksi torium, serta reagen analisis yang terdiri atas $\mathrm{HNO}_{3}$, asam askorbat, NaF, TOPO, Br-PADAP, larutan kompleks II, larutan buffer, torin, asam oksalat, dan kertas saring Whatman nomor 42.

\section{Alat}

Gelas beker, gelas ukur, pengaduk magnetik, corong pemisah, timbangan analitik, labu ukur, mikropipet, stopwatch, hot plate, $\mathrm{pH}$ meter, termometer, pompa vakum, seperangkat spektrofotometer UV-Vis, furnace.

\section{Langkah Kerja}

\section{Penyiapan Umpan Ekstraksi Torium}

Larutan (U, Th, RE) $\mathrm{SO}_{4}$ diekstraksi dengan campuran TOA, kerosen, dan isodekanol dengan perbandingan volume 5:92:3 dan perbandingan umpan dengan pelarut 1:5 selama 5 menit, kemudian fase organik dan aqueous dipisahkan dengan corong pemisah. Fase aqueous (rafinat) diendapkan dengan $\mathrm{NH}_{4} \mathrm{OH} 20 \%$ hingga tercapai $\mathrm{pH}$ 6,3 selama 1 jam, kemudian residu dilarutkan dengan $\mathrm{HNO}_{3} 5 \mathrm{M}$.

\section{Penentuan Kondisi Optimum Ekstraksi}

Larutan torium nitrat diekstraksi menggunakan TBP/kerosen (40/60) dengan perbandingan A/O 1:1 selama 5 menit, kemudian dilakukan pemisahan organik dari aqueous. Waktu ekstraksi divariasi. Kadar U, Th, dan RE dalam fase aqueous dianalisis. Larutan torium nitrat $\mathrm{pH} 2$ diekstraksi menggunakan TBP/kerosen (40/60) dengan A/O 1:1 selama waktu setimbang yang telah diperoleh. $\mathrm{pH}$ divariasi. Ekstraksi dilanjutkan dengan variasi konsentrasi solvent dan perbandingan $\mathrm{A} / \mathrm{O}$ menggunakan kondisi terbaik yang diperoleh dari variasi sebelumnya.

\section{Penentuan Kondisi Optimum Stripping}

Larutan torium nitrat diekstraksi menggunakan kondisi terbaik yang telah diperoleh. Fase organik dipisah dari fase aqueous, kemudian di-stripping menggunakan $\mathrm{HNO}_{3}$ 0,5 $\mathrm{N}$ dengan perbandingan A/O 1:1 selama 5 menit. Waktu stripping divariasi. Kadar U, Th, dan RE dalam fase aqueous dianalisis. Waktu setimbang digunakan untuk mencari kondisi keasaman $\mathrm{HNO}_{3}$ terbaik dengan melakukan variasi konsentrasi $\mathrm{HNO}_{3}$.

\section{Penentuan Jumlah Stage}

Koefisien distribusi (Kd) dihitung menggunakan Persamaan (1). Kd yang diperoleh digunakan untuk membuat kurva kesetimbangan. Garis operasi dibuat dengan menghubungkan titik $\mathrm{P}\left(\mathrm{X}_{\mathrm{F}}, \mathrm{Y}_{1}\right)$ dan $\mathrm{Q}\left(\mathrm{X}_{\mathrm{n}}, \mathrm{Y}_{\mathrm{n}+1}\left(=\mathrm{Y}_{\mathrm{s}}\right)\right)$. Garis horizontal ditarik ke kiri dari titik konsentrasi awal pada garis operasi, menyinggung garis kesetimbangan, dan dari titik tersebut ditarik garis vertikal ke bawah menyinggung garis operasi. Banyaknya segitiga yang terbentuk dihitung sebagai jumlah stage teoretis. Hasil metode grafik kemudian dibandingkan dengan metode shortcut berdasarkan Persamaan (8) dan (9).

\section{Analisis Uranium}

Sampel yang mengandung uranium dipipet ke dalam labu kocok, kemudian ditambahkan $15 \mathrm{ml} \mathrm{HNO}_{3} 2,5 \mathrm{~N}, 2 \mathrm{ml}$ asam askorbat 5\%, $1 \mathrm{ml} \mathrm{NaF}$, dan $5 \mathrm{ml}$ larutan TOPO $0,05 \mathrm{~N}$. Campuran dikocok selama 2 menit dan dibiarkan sampai fase organik dan fase cair terpisah. Fase organik dipipet sebanyak $2 \mathrm{ml}$ ke dalam labu ukur $25 \mathrm{ml}$, lalu ditambahkan $1 \mathrm{ml}$ larutan kompleks II, $1 \mathrm{ml}$ larutan buffer $\mathrm{pH}$ 8,35, dan $2 \mathrm{ml}$ Br-PADAP 0,05\%, kemudian dibiarkan selama 10 menit dan ditandabataskan dengan etanol. Konsentrasi U dalam sampel diukur dengan spektrofotometer UV-Vis pada panjang gelombang $574 \mathrm{~nm}$ menggunakan kurva standar uranium.

\section{Analisis Torium}

Sampel dipipet ke dalam labu ukur $50 \mathrm{ml}$, ditambahkan $5 \mathrm{ml}$ asam askorbat $5 \%$ dan $5 \mathrm{ml}$ torin, kemudian ditandabataskan dengan larutan $\mathrm{HCl} \mathrm{pH} 0,8$. Konsentrasi Th dalam sampel diukur dengan spektrofotometer UVVis pada panjang gelombang $545 \mathrm{~nm}$ menggunakan kurva standar torium.

\section{Analisis LTJ}

Sampel dipipet ke dalam gelas beker, kemudian ditambah $30 \mathrm{ml}$ akuades. $\mathrm{pH}$ larutan dikondisikan menjadi 1. Larutan diendapkan dengan $15 \mathrm{ml}$ asam oksalat $10 \%$ dan dibiarkan selama semalam sampai endapannya mengendap. Endapan disaring, dibiarkan 
kering, kemudian dibakar pada suhu $800{ }^{\circ} \mathrm{C}$. Endapan $\mathrm{RE}_{2} \mathrm{O}_{3}$ didinginkan dan ditimbang.

\section{HASIL DAN PEMBAHASAN}

\section{Umpan Ekstraksi}

Berdasarkan data Basic Engineering Design PTBGN-BATAN, hasil samping pilot plant logam tanah jarang $50 \mathrm{~kg} / \mathrm{hari}$ masih mengandung $\quad 0,78 \% \quad \mathrm{UO}_{2}(\mathrm{OH})_{2}, \quad 8,12 \%$ $\mathrm{Th}(\mathrm{OH})_{4}$, dan $7,06 \% \mathrm{RE}(\mathrm{OH})_{3}$. Hasil samping tersebut merupakan hasil samping pada proses pelarutan parsial seperti pada Gambar 1 .

Pada penelitian ini dilakukan ekstraksi torium dari rafinat hasil ekstraksi uranium monasit Bangka. Pada ekstraksi uranium, umpan yang digunakan adalah hasil samping pengolahan monasit yang telah dikondisikan menjadi larutan sulfat. Konsentrasi umpan ekstraksi yang digunakan yaitu Th 1,23\%, U 411,4 ppm, dan $\mathrm{RE}_{2} \mathrm{O}_{3}$ 2,86\%. Ekstraksi uranium dilakukan menggunakan solvent TOA dengan kondisi optimum, yakni selama 5 menit, $\mathrm{pH}$ umpan 1,5 , perbandingan $\mathrm{A} / \mathrm{O}=$ 1/5, dan TOA/kerosen/isodekanol $=5: 92: 3$. [5] . Dengan menggunakan kondisi tersebut, diperoleh recovery aqueous untuk unsur Th sebesar $81,10 \%, \mathrm{RE}_{2} \mathrm{O}_{3} 96,50 \%$, dan U tidak terdeteksi. Dalam rafinat sebenarnya mungkin masih ada uranium, namun dalam konsentrasi sangat kecil sehingga tidak dapat terdeteksi oleh larutan standar 5 ppm sampai 200 ppm dengan menggunakan spektrofotometer UVVis.

Aqueous dari ekstraksi merupakan larutan sulfat sehingga harus diubah menjadi larutan nitrat agar dapat diekstraksi dengan TBP. Rafinat ekstraksi diendapkan terlebih dahulu pada $\mathrm{pH}$ 6,3 selama 1 jam. Pengendapan pada $\mathrm{pH}$ tersebut bertujuan untuk meminimalkan logam tanah jarang. Berdasarkan pengendapan tersebut diperoleh recovery endapan untuk unsur Th sebesar $98,73 \%, \mathrm{RE}_{2} \mathrm{O}_{3} 65,73 \%$, dan U tidak terdeteksi. Endapan dilarutkan dengan $\mathrm{HNO}_{3} 5 \mathrm{~N}$ dengan recovery Th $54,22 \%$ dan $\mathrm{RE}_{2} \mathrm{O}_{3} 74,63 \%$.

\section{Ekstraksi Torium}

Untuk melihat pengaruh $\mathrm{pH}$ terhadap koefisien distribusi, dilakukan pencarian waktu setimbang terlebih dulu. Hal ini disebabkan karena koefisien distribusi merupakan perbandingan konsentrasi dari solute dalam satu fase cair dengan konsentrasi solute dalam fase cair lainnya pada saat setimbang. Berdasarkan percobaan diperoleh waktu setimbang 15 menit seperti pada Gambar 6 . Pada waktu 15 menit dan waktu 25 menit koefisien distribusi yang diperoleh hampir sama. Ketika waktu bertambah menjadi 35 menit, nilai koefisien distribusi pun tidak jauh berbeda.

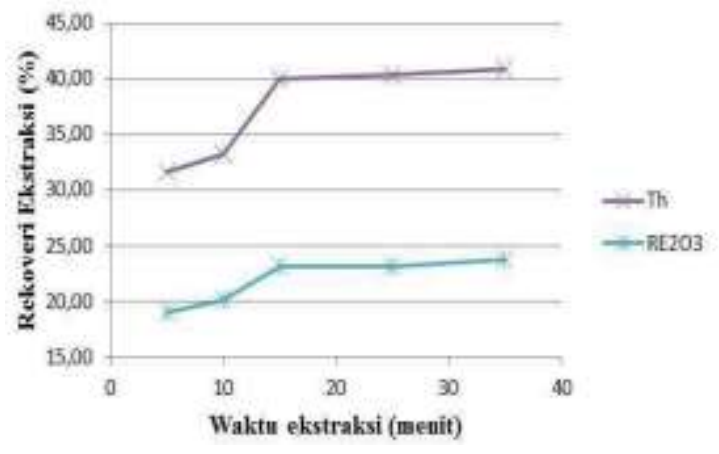

(a)

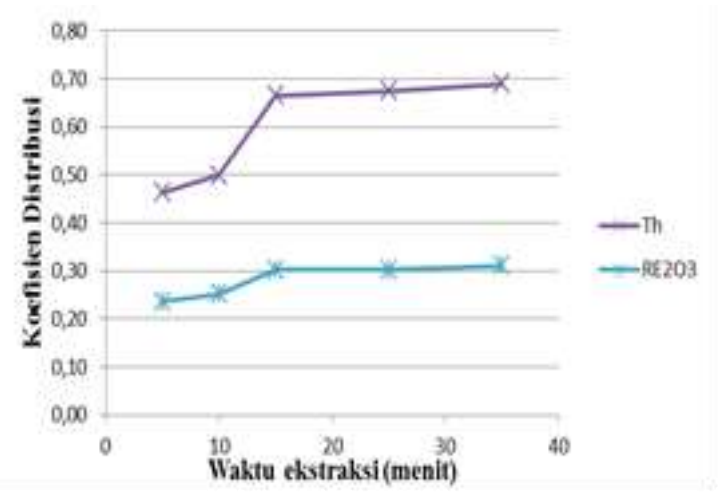

(b)

Gambar 6. Grafik Hubungan Waktu dengan (a) Recovery Ekstraksi dan (b) Koefisien Distribusi

Waktu setimbang tersebut digunakan untuk mencari kondisi $\mathrm{pH}$ umpan. Berdasarkan Gambar 7 dapat diketahui bahwa semakin tinggi keasaman umpan, semakin banyak torium maupun logam tanah jarang yang terekstrak. Berdasarkan percobaan diperoleh $\mathrm{pH}$ umpan terbaik yaitu 0,09 dengan efisiensi ekstraksi torium 84,74\% dan $\mathrm{RE}_{2} \mathrm{O}_{3} 57,14 \%$ serta koefisien distribusi torium 5,55 dan koefisien distribusi $\mathrm{RE}_{2} \mathrm{O}_{3}$ 1,33. Meskipun torium yang terekstrak banyak, logam tanah jarang yang ikut terekstrak juga cukup banyak. Hal ini dapat disebabkan oleh ekstraktan yang digunakan kurang selektif. 


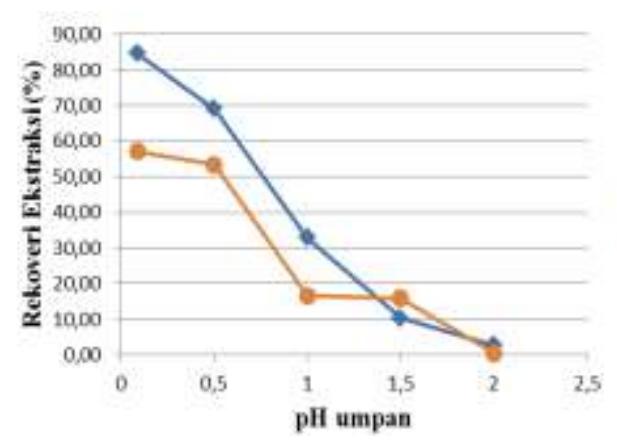

(a)

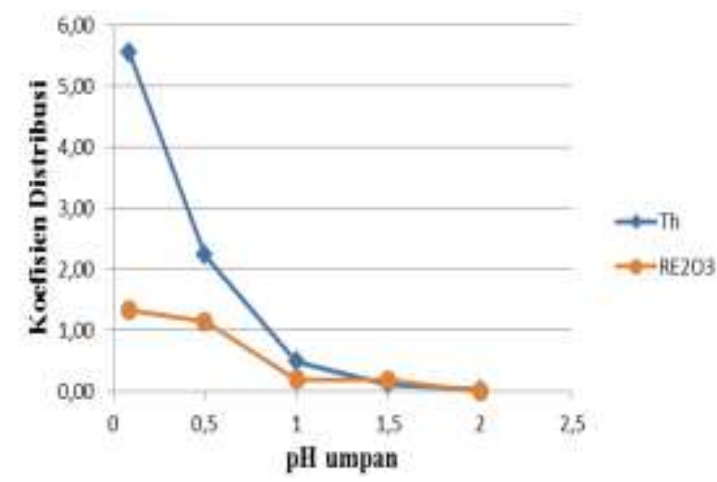

(b)

Gambar 7. Grafik Hubungan $\mathrm{pH}$ Umpan dengan (a) Recovery Ekstraksi dan (b) Koefisien Distribusi

Koefisien distribusi yang diperoleh di bawah koefisien distribusi penelitian Suyanti dan Suprihati serta penelitian Setyadji dan Susiantini. Pada percobaan Suyanti dengan kondisi optimum waktu ekstraksi 25 menit, konsentrasi $\mathrm{HNO}_{3} 5 \mathrm{M}$, TBP/kerosen 30/70, dan perbandingan $\mathrm{A} / \mathrm{O}$ 1/1 diperoleh koefisien distribusi torium sebesar 20,509 [9]. Hal ini disebabkan oleh $\mathrm{HNO}_{3} 5 \mathrm{M}$ yang digunakan berlebih sehingga $\mathrm{pH}$ umpan di bawah 0,09 .

Berbeda dengan penelitian Suyanti, pada penelitian Setyadji dengan waktu ekstraksi 20 menit, keasaman $3 \mathrm{~N}$, TBP/kerosen 50/50, dan perbandingan $\mathrm{A} / \mathrm{O} \quad 1 / 2$ diperoleh koefisien distribusi torium sebesar 15,356 [11]. Hal ini disebabkan oleh keasaman dan konsentrasi ekstraktan yang berbeda. Oleh sebab itu, perlu dilakukan penentuan konsentrasi ekstraktan.

Berdasarkan Gambar 8, semakin tinggi konsentrasi TBP yang digunakan maka koefisien distribusi dan recovery semakin meningkat. Hal ini disebabkan oleh pasangan elektron bebas pada TBP lebih banyak sehingga dapat mengikat torium lebih banyak. Konsentrasi TBP optimum yang dipilih yaitu 50\% karena dikhawatirkan densitas ekstraktan pada konsentrasi TBP yang lebih tinggi masih mendekati densitas air sehingga diperlukan pemisahan yang lebih lama. Pada konsentrasi $50 \%$ diperoleh koefisien distribusi sebesar 13,79 .

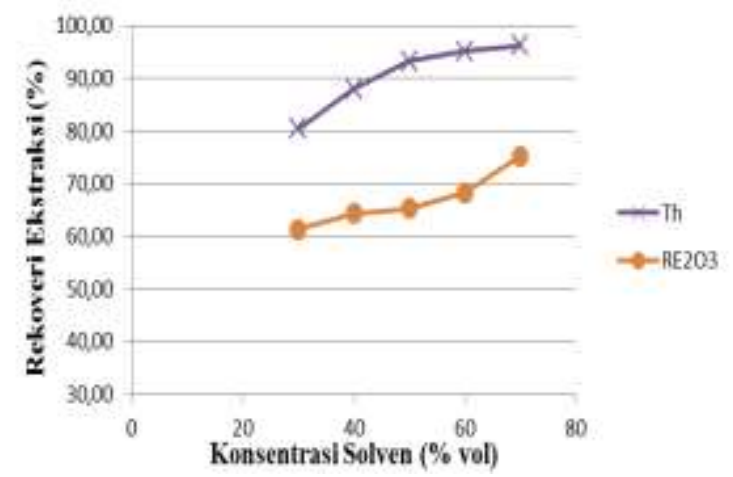

(a)

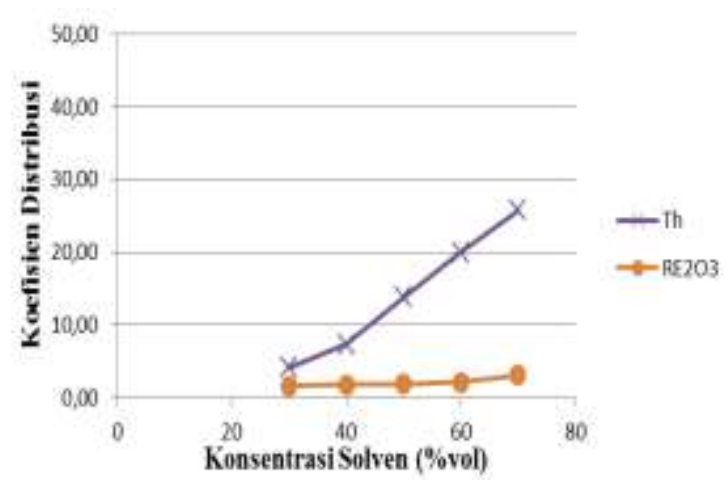

(b)

Gambar 8. Grafik Hubungan Konsentrasi Solvent dengan (a) Recovery Ektraksi dan (b) Koefisien Distribusi

Koefisien distribusi yang diperoleh tidak jauh berbeda dengan percobaan Setyadji meskipun Setyadji menggunakan perbandingan $\mathrm{O} / \mathrm{A}$ 1/2. Berdasarkan persamaan koefisien distribusi, perbandingan O/A tidak mempengaruhi $\mathrm{Kd}$ sehingga $\mathrm{Kd}$ dapat dijadikan landasan untuk menentukan jumlah stage ekstraksi dalam industri. Perbandingan O/A berpengaruh terhadap recovery ekstraksi yang diperoleh. Semakin banyak organik yang ditambahkan maka semakin besar recovery yang diperoleh. Pengaruh O/A terhadap koefisien distribusi dan recovery ekstraksi ditunjukkan pada Gambar 9. 


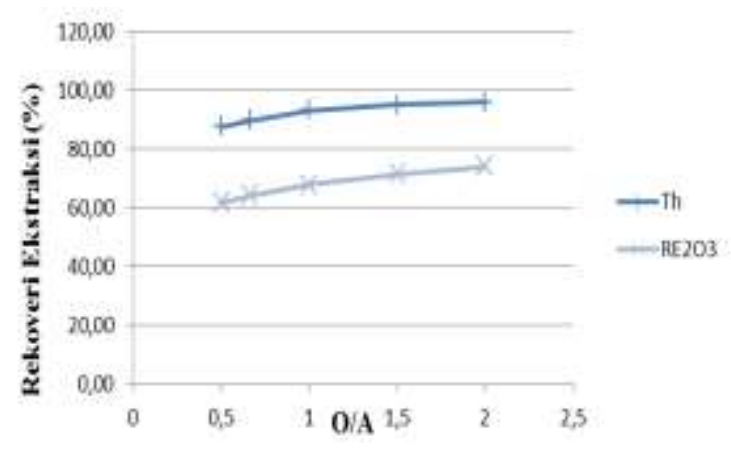

(a)

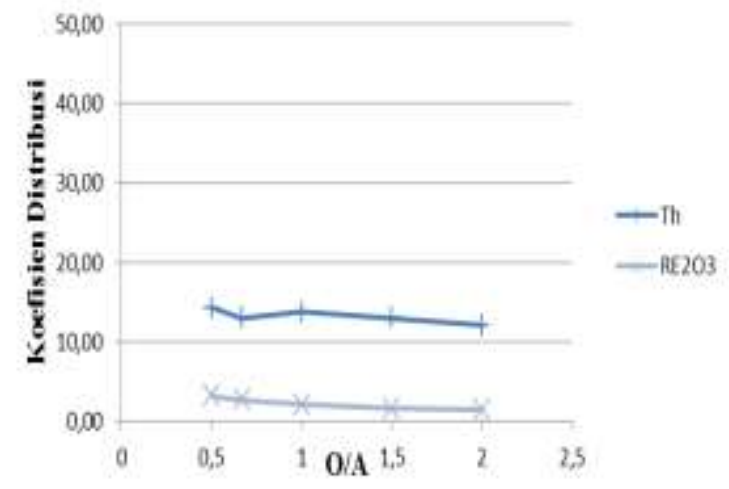

(b)

Gambar 9. Grafik Hubungan Rasio A/O dengan (a) Recovery Ekstraksi dan (b) Koefisien Distribusi

Koefisien distribusi yang diperoleh dari percobaan dapat digunakan untuk menghitung jumlah stage ekstraksi. Penentuan stage dilakukan berdasarkan ekstraksi multistage countercurrent mengingat ekstraksi ini sering diterapkan dalam industri karena menghasilkan recovery cukup tinggi. Jumlah stage dihitung dengan metode grafik McCabe-Thiele dan metode shortcut. Dengan memasukkan data konsentrasi unsur dalam fase aqueous, dapat dihitung konsentrasi unsur dalam fase organik. Garis kesetimbangan dibuat dengan $\mathrm{X}-\mathrm{Y}$ diagram. Konsentrasi unsur dalam fase aqueous dinyatakan dengan $\mathrm{X}$ dan konsentrasi unsur dalam organik dinyatakan dengan $\mathrm{Y}$.

Selain itu, perlu dibuat garis operasi dengan menghubungkan dua koordinat, yaitu titik $\mathrm{P}\left(\mathrm{X}_{\mathrm{F}}, \mathrm{Y}_{\mathrm{e}}=\mathrm{Y}_{\mathrm{N}}\right)$ dan $\mathrm{Q}\left(\mathrm{X}_{\mathrm{r}}=\mathrm{X}_{1}, \mathrm{Y}_{\mathrm{s}}=\mathrm{Y}_{0}\right)$. Berdasarkan metode grafik McCabe-Thiele dapat diketahui bahwa untuk memperoleh recovery torium $95 \%$, stage yang dibutuhkan adalah 1 (satu) stage, seperti pada Gambar 10. Dalam perancangan, digunakan tahap $\mathrm{n}+1$ atau tahap aktual untuk memberikan over design sehingga jumlah stage yang dibutuhkan adalah 2 (dua) stage. Untuk memastikan ketepatan grafik tersebut, dilakukan perhitungan dengan persamaan Kremser. Hasil yang diperoleh adalah 1,18. Jika digunakan perhitungan $\mathrm{n}+1$, maka hasil tersebut juga sama dengan hasil pada metode grafik.

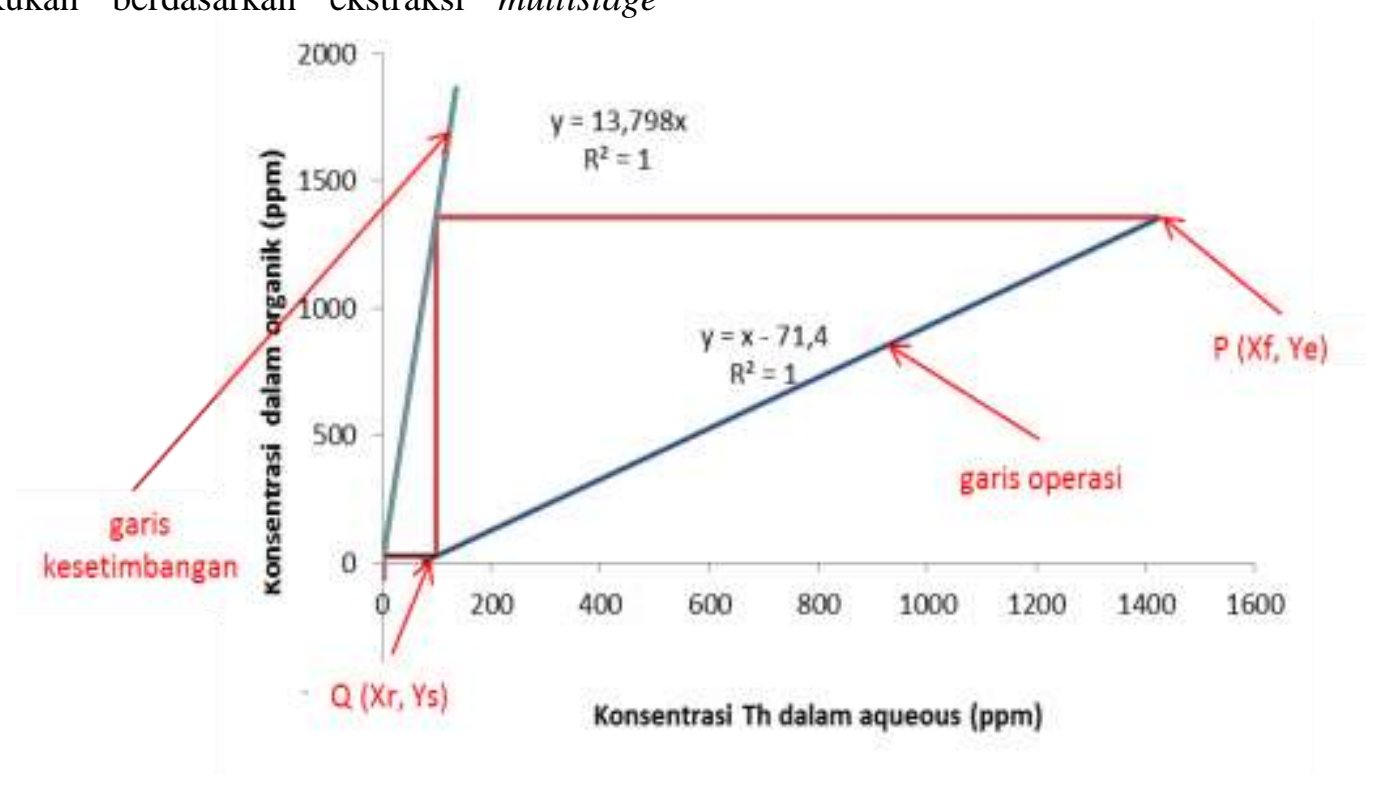

Gambar 10. Kurva Penentuan Jumlah Stage Ekstraksi Torium 


\section{Stripping}

Untuk memperoleh nilai koefisien distribusi stripping, terlebih dahulu dicari waktu setimbangnya. Berdasarkan percobaan, diperoleh waktu setimbang 15 menit seperti yang ditunjukkan pada Gambar 11.

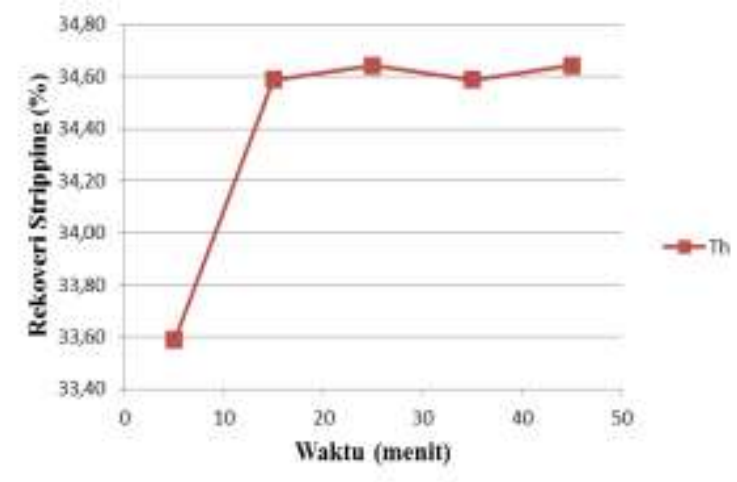

(a)

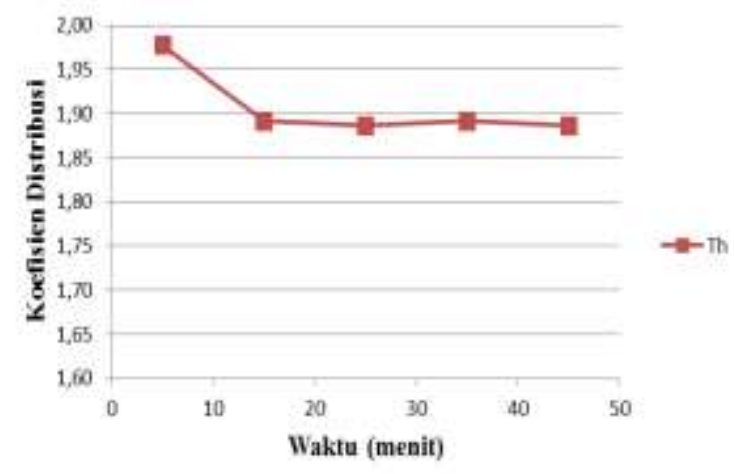

(b)

Gambar 11. Grafik Hubungan Waktu Stripping dengan (a) Recovery Stripping dan (b) Koefisien Distribusi.

Waktu setimbang kemudian digunakan untuk menentukan konsentrasi stripper. Semakin tinggi konsentrasi stripper, nilai koefisien distribusi semakin tinggi dan recovery semakin turun, seperti yang ditunjukkan pada Gambar 12. Namun, pada konsentrasi 0 koefisien distribusi torium menurun. Larutan stripper dengan keasaman rendah mampu menarik Th ke dalam larutan asam nitrat karena afinitas $\mathrm{Th}^{4+}$ terhadap $\mathrm{NO}_{3}{ }^{-}$ lebih besar daripada afinitas LTJ [9]. Pada konsentrasi yang lebih tinggi, pembentukan kompleks torium nitrat tidak sempurna [10]. Berdasarkan percobaan diperoleh koefisien distribusi sebesar 1,57 dan recovery Th sebesar $38,92 \%$.

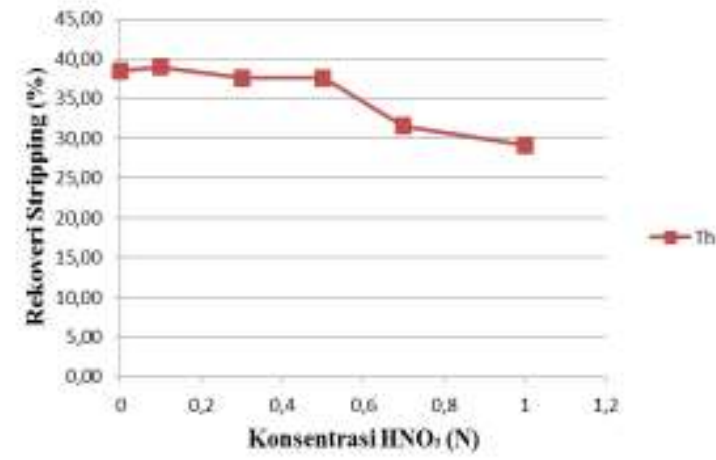

(a)

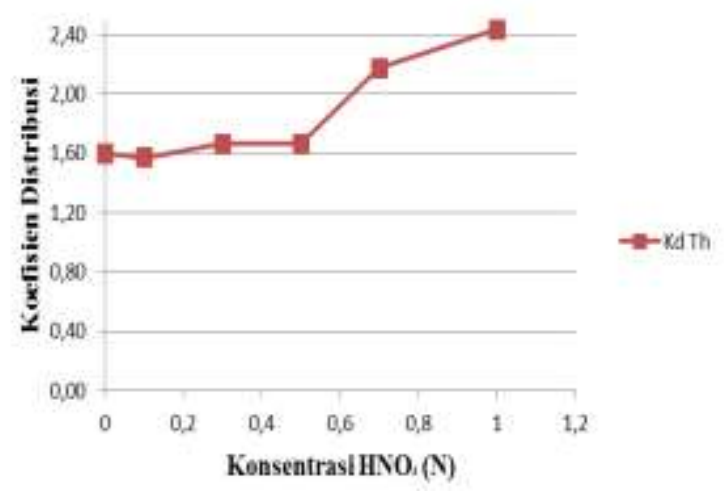

(b)

Grafik 12. Grafik Hubungan Konsentrasi $\mathrm{HNO}_{3}$ dengan (a) Recovery Stripping dan (b) Koefisien Distribusi

Jumlah stage stripping dapat dihitung menggunakan grafik metode McCabe-Thiele, sama seperti pada ekstraksi. Untuk perbandingan $\mathrm{A} / \mathrm{O}=1$, jumlah stage tidak dapat dihitung. Hal ini disebabkan nilai koefisien distribusi yang kecil, yaitu 1,57 dan recovery Th yang hanya 38,92\% sehingga diperlukan stage yang sangat banyak. Selain itu, slope garis operasi lebih besar daripada slope garis kesetimbangan, seperti yang tampak pada Gambar 13. Oleh sebab itu, agar dapat dihitung maka volume solvent perlu ditambah. Untuk mendapatkan recovery torium $95 \%$, jika perbandingan $\mathrm{A} / \mathrm{O}=2 / 1$, maka dibutuhkan 7 stage berdasarkan grafik dan 6,71 stage berdasarkan metode shortcut. Sementara itu, jika perbandingan $\mathrm{A} / \mathrm{O}=3 / 1$ maka dibutuhkan 4 stage berdasarkan grafik dan 3,56 stage berdasarkan metode shortcut. Untuk memberikan over design, maka jumlah stage yang dibutuhkan sebanyak 8 stage untuk perbandingan $\mathrm{A} / \mathrm{O}=2$ dan 5 stage untuk perbandingan $\mathrm{A} / \mathrm{O}=3$. Jadi, jumlah stage yang dibutuhkan bergantung pada perbandingan A/O. Semakin banyak jumlah solvent, maka 
jumlah stage yang dibutuhkan semakin sedikit. Dalam industri, menentukan jumlah stage ini memerlukan analisis ekonomi, baik bahan yang dibutuhkan, alat, maupun biaya perawatan alat.

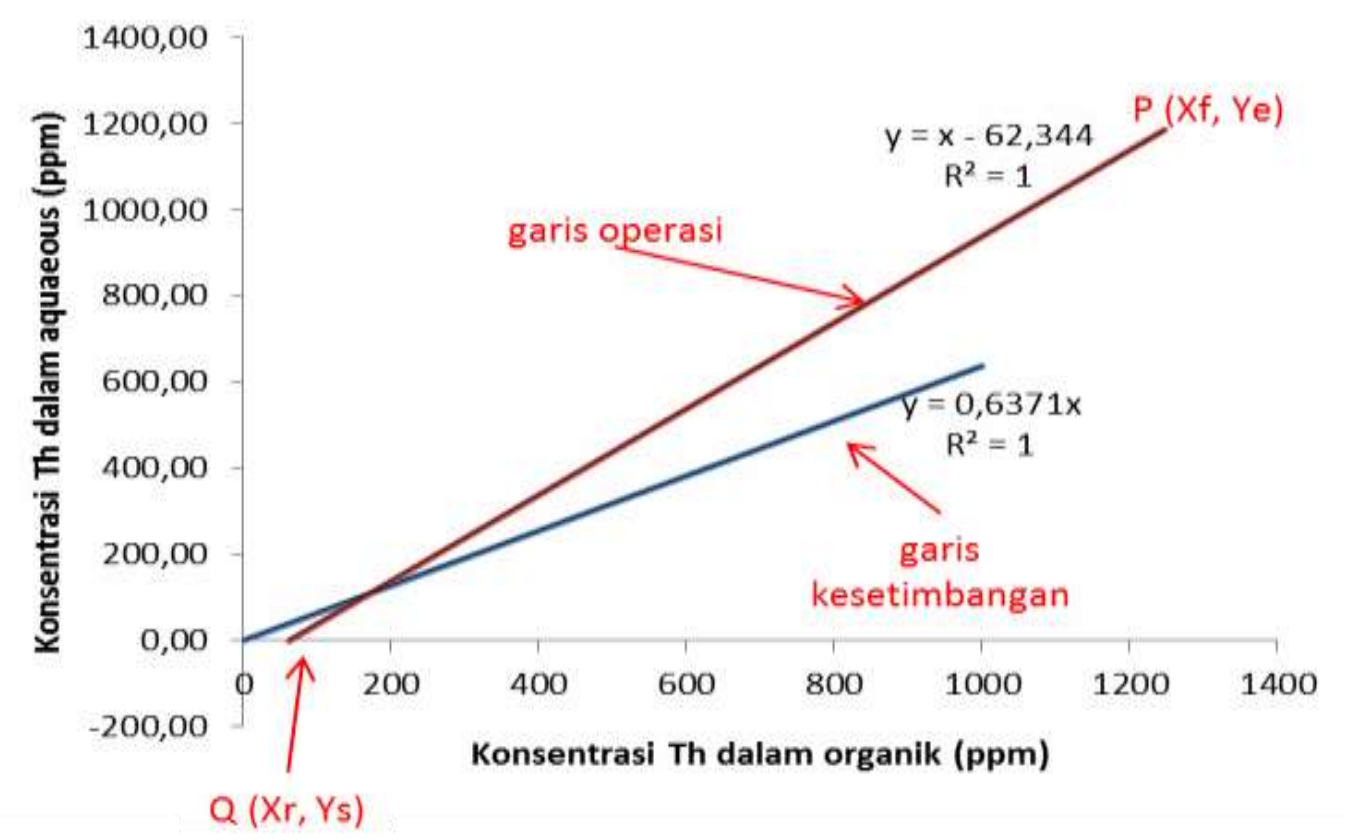

Gambar 13. Kurva Penentuan Jumlah Stage Stripping Torium dengan A/O = 1

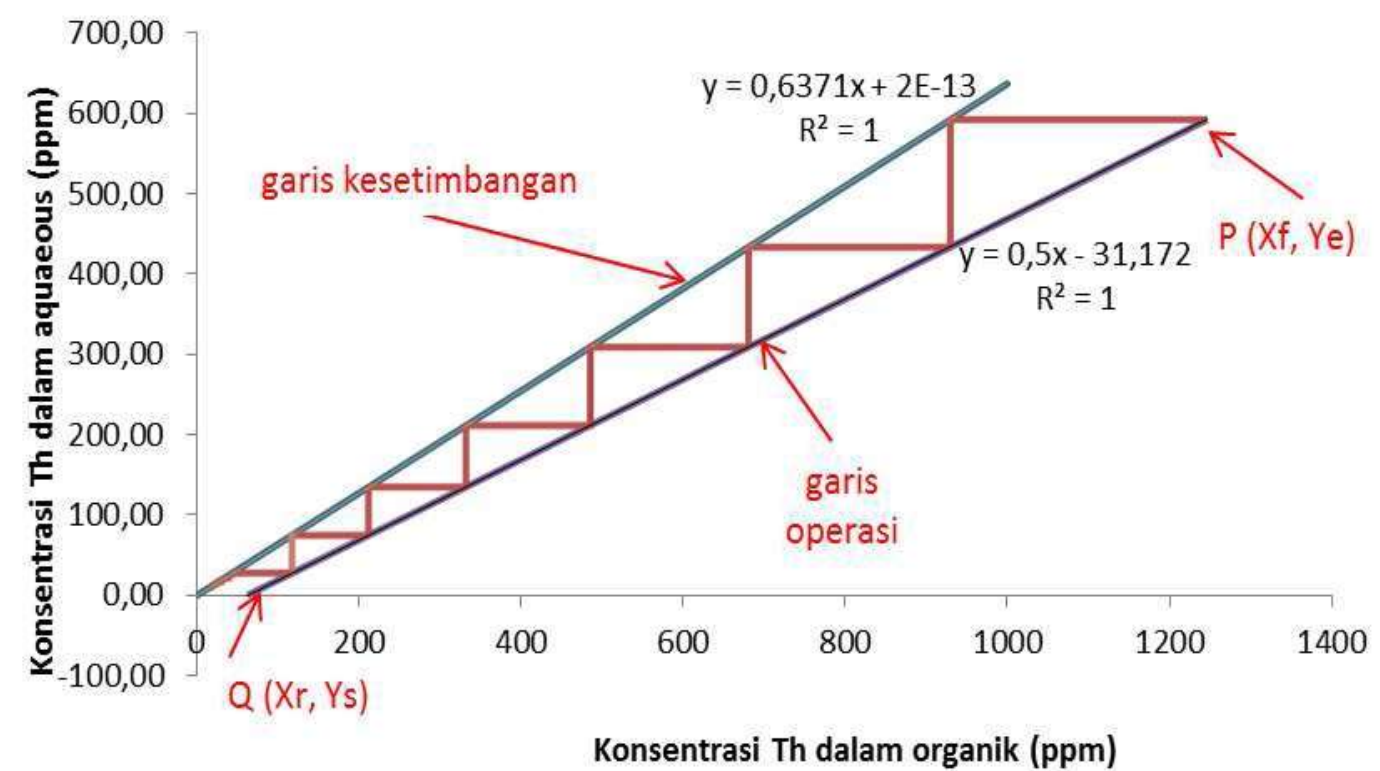

Gambar 14. Kurva Penentuan Jumlah Stage Stripping Torium dengan A/O = 2 


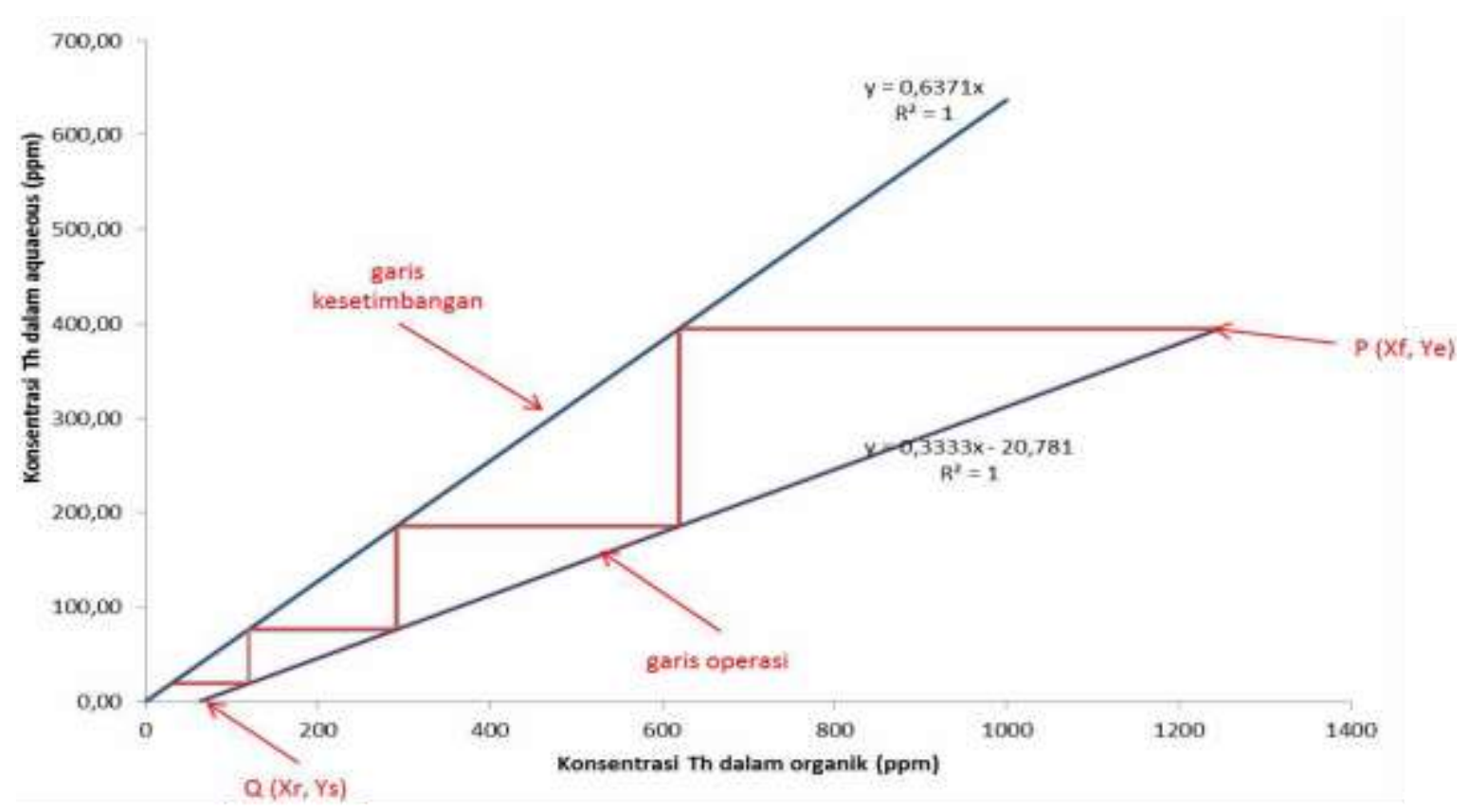

Gambar 15. Kurva Penentuan Jumlah Stage Stripping Torium dengan A/O = 3

\section{KESIMPULAN}

Berdasarkan penelitian ini, dapat diambil kesimpulan sebagai berikut.

1. Semakin tinggi keasaman umpan, maka recovery dan koefisien distribusi torium semakin meningkat.

2. Semakin tinggi konsentrasi $\mathrm{HNO}_{3}$, maka recovery semakin menurun dan koefisien distribusi torium dalam stripping semakin meningkat.

3. Untuk memperoleh recovery torium $95 \%$, ekstraksi dengan waktu 15 menit, 50\% TBP dan 50\% kerosen, serta perbandingan $\mathrm{A} / \mathrm{O}=1$, dibutuhkan 2 stage. Sementara itu, stripping dengan waktu 15 menit, dan $\mathrm{HNO}_{3} \quad 0,1 \quad \mathrm{~N}$, membutuhkan 8 stage stripping pada perbandingan $\mathrm{A} / \mathrm{O}=2$ dan 5 stage stripping pada perbandingan $\mathrm{A} / \mathrm{O}$ $=3$.

\section{SARAN}

1. Unsur logam tanah jarang perlu dianalisis secara individual dengan menggunakan metode analisis yang lebih akurat.

2. TBP sebagai ekstraktan kurang selektif dalam pemisahan torium sehingga perlu dicari ekstraktan lain yang lebih selektif.

3. Jika akan menerapkan jumlah stage ekstraksi-stripping ke skala yang lebih besar, perlu diperhitungkan faktor ekonomi dan keselamatan.

\section{DAFTAR PUSTAKA}

1. Susilaningtyas, Erni R.A., L.N. Hafni, R. Faisal, 1999. "Pengolahan Monasit Bangka Menjadi Konsentrat Tanah Jarang Hidroksida." dalam: Seminar Nasional Pranata Nuklir II. Jakarta.

2. Nuri, H.L., Riza, Faizal, Susilaningtyas, S. Waluyo, dan E.R. Arief, 2004. "Aplikasi Peralatan Proses Monasit Skala Laboratorium untuk Pengolahan Monasit Bangka menjadi Rare Earth Oksida dengan Kapasitas $1 \mathrm{~kg} / \mathrm{hari"} \mathrm{dalam:}$ Seminar Geologi Nuklir dan Sumber Daya Tambang Tahun 2004. Jakarta: Pusat Pengembangan Bahan Galian dan Geologi Nuklir BATAN.

3. Sumaryanto, Agus, 2012. "Uranium and Thorium Exploration Activities and Their Processing Research in Indonesia." dalam: Slide Presentasi dalam acara Interregional IAEA-CYTED-UNECE Workshop on Recent Developments in Evaluation of Uranium and Thorium Resources. Portugal.

4. Burke, T.J., May 1982. The Characterization of Commercial Thorium Oxide Powders. Pennsylvania: Bettis Atomic Power Laboratory.

5. Trinopiawan, K., R. Prassanti, Sumarni, dan R. Pudjianto, 2012. "Pemisahan U dari Th pada Monasit dengan Metode Ekstraksi 
Pelarut Alamine." dalam: Prosiding Geologi Nuklir dan Sumber Daya Tambang Pusat Pengembangan Geologi Nuklir-BATAN. Jakarta.

6. Cuthbert, F.L, 1958. Thorium Production Technology. Addison Wesley Publishing Company Inc., USA.

7. Benedict, M., T.H. Pigfoth, and H.W. Levi, 1981. Nuclear Chemical Engineering. New York: McGraw-Hill Book Company.

8. Perry, R.H and D.W. Green, 1999. Perry's Chemical Engineers' Handbook. New York: McGraw-Hill Book Company.

9. Suyanti dan Suprihati, 2010. "Pemurnian Torium dengan Cara Ekstraksi Memakai Tributil Fosfat." dalam: Prosiding PPI-
PDIPTN Pustek Akselerator dan Proses Bahan-BATAN. Yogyakarta.

10. Patkar, S.N., A.S. Burungale, dan R.J. Patil, 2009. "Separation and Liquid-Liquid Extraction of Thorium (IV) as Sulfate Complex with Synergistic Mixture of N-nOctylaniline and Trioctylamine as an Extractant." in: Rasayan J. Chem. India: Department of Chemistry, Karnaveer Bhaurao Patil College.

11. Setyadji, Moch. dan Endang Susiantini, 2002. Pengaruh Prosen TBP dan Perbandingan Umpan dan Pelarut pada Ekstraksi Uranium-Thorium Proses Thorex. Yogyakarta: Puslitbang Teknologi Maju BATAN. 